\title{
Effects of oil spillage on soils nutrients of selected communities in Ogoniland, south-eastern Niger Delta, Rivers State, Nigeria
}

\section{Ayodele A. Otaiku}

Department of Geography and Environmental Management, Faculty of Social Science, University of Port Harcourt, Choba, Port Harcourt, Rivers State, Nigeria.

Accepted 7 January, 2019

HIGHLIGHTS

Hydrocarbon pollution Ogoniland degradation Rhizosphere microbes Biodiversity

Critical nutrient concentrations

Restoration

Agro-ecology

Niger Delta
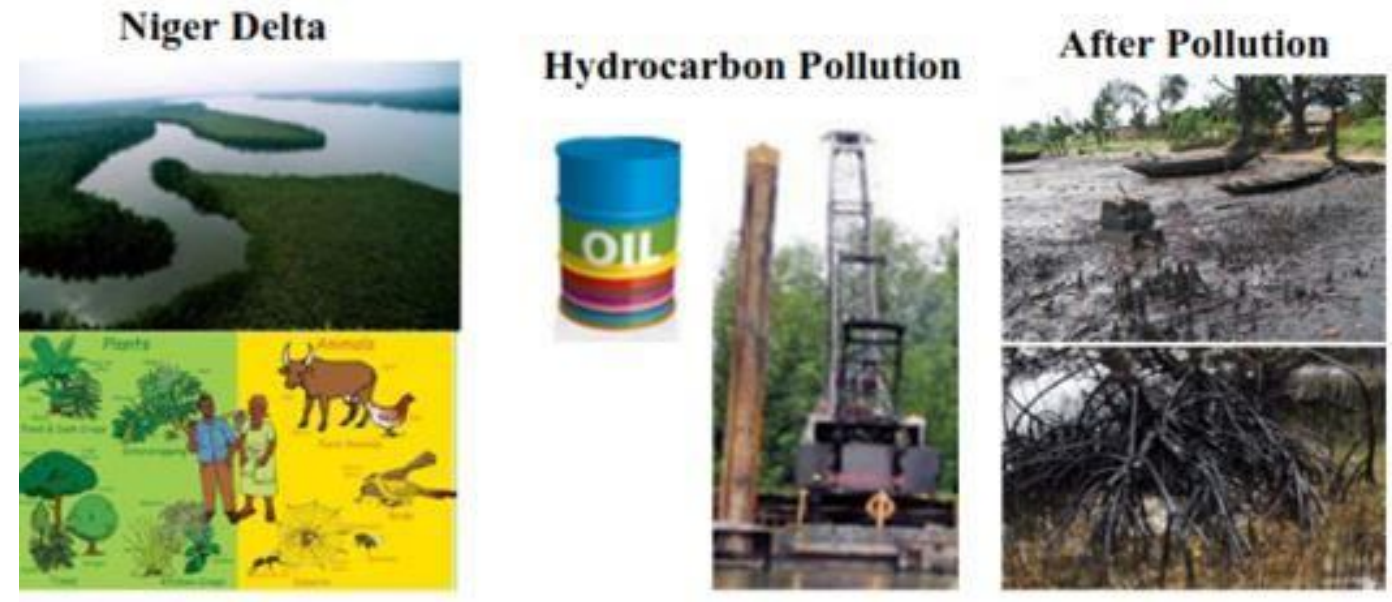

\begin{abstract}
Crude hydrocarbon spill and exploration activities destroy biodiversity of study locations ecosystem and inhibitory to plant growth in polluted soils (Ultisols) in selected communities (Zaakpon, Kpean, Yorla and Gure) at 0-30 cm depths in Ogoniland, Niger Delta, Nigeria and study conducted June-August, 2004.The aesthetic, agro-ecology and environmental biodiversity quality of selected communities impaired by the multinational oil companies. Data analyses variance, mean by Duncan multiple range test (SAS, 1985) over locations, depths, macronutrients and micronutrients of the selected communities at least significant difference $\mathrm{P}<0.1$ for the polluted and unpolluted soils. The impacted soils localized between $0-15 \mathrm{~cm}$ depths with low organic matter contents (<1\% Org. carbon) and high $\mathrm{C} / \mathrm{N}$ ratios at Gure (11.58), Zaakpon (52.95) and Kpean (25.49) results to low microbial activity and poor vegetative landscape except at Yorla with $\mathrm{C} / \mathrm{N}$ 8.66 that support biodiversity ecological services. Forest ecosystems react sensitively to the soils 2.8 highly acidic with $\mathrm{pH}$ value and that will requires soil amendments for soil nutrients enhancement for biodegradation and restoration ecology. The impacted soils fertility analyses of crops tolerant to nutritional imbalance of the study area are: maize, banana, cassava, mango, pineapple, sweet potato and tomatoes base on their critical nutrient concentrations of the crops yield.
\end{abstract}

Keywords: Bioremediation, soil nutrient, Ogoniland, carbon/nitrogen ratio, crude hydrocarbon pollution, Niger Delta, microbial inoculant, manure, climatic change, crops yield, restoration ecology.

Email: aotaiku@gmail.com. Tel: +234 8033721219. 


\section{INTRODUCTION}

Soil, a heterogeneous made up of inorganic solids, organic (humic) solids gases, and liquids (Paul and Clark, 1989), when contaminated with hydrocarbons causes extensive damage of local ecosystems since accumulation of pollutants in animals and plants tissues cause progeny's death or mutation (Alvarez et al., 1991). Organic contaminants (Polychlorinated biphenyls, PCBs; Polycyclic aromatic hydrocarbons, PAHs) [Edwards, 1983; Fries, 1982; O'Connor, 1998] contaminate forage on which livestock graze (Wilson, 1987). Hydrocarbons are inhibitory to plant growth (Chaîneau et al., 1998) because it is composed of various proportions BTEX (e.g. benzene, toluene, ethylbenzene, and zylene (Lyons, 1996; Bedient, 1994). Legally acceptable hydrocarbon waste disposal methods are: incineration, deep well injection, burial in a secure chemical landfill, or land treatment (land farming) by Sahastrabudhe and Modi (1986).

Four bacterial genera were identified in the bacteria consortium named, Pseudomona, Serratia, Acinetobacter and Flavobacteria, most of them have reported as hydrocarbon utilizers (Atlas, 1981). The deficiency of available nitrate nitrogen often observed as being reported by the local farmers in their low produce may be caused by an inadequate population of nitrate oxidizer. The ecological impacts of oil exploration, drilling and spills studies (Abe and Ayodele, 1983; Envir-Health Consultant, 1995) confirmed destruction of the ecosystems and symptoms of nutrient deficiencies and toxicities result from impaired metabolism with the plant, nutrient deficiency and toxicology experienced by plants on a petroleum soil and colloidal organic matter aid pollutants transport (Herbert et al., 1993).

Hydrocarbon environmental degradation of priority pollutants and microorganisms is a challenge to crude hydrocarbon producing countries (Onweremadu et al., 2008; Aiyesanmi, 2005) with resultant impacts of unavailability of essential plant nutrients such as nitrogen, and the availability of some toxic elements such as arsenic, and lead to plants (Akamigbo and Jidere, 2002; Gill et al., 2003). Crude oil had a dispersive effect on sprouting of ginger while it had variable effects on the microbial biomass (Ekpo and Nwankpa, 2006). It weakens soil microbes thereby inhibiting their activity (Manahan, 1994) and influences plant root development (Ekpo, 2002), soil water absorption by plants (Atuanya, 1987), biotoxicity (Atuanya, 1987), soil structure, water stress and nutrients deficiencies (Odjegba and Sadig, 2002; Gill et al., 2003) and decline in crop performance (Gaskin et al., 2007).

Heavy metals associated with crude oil spillage are naturally found in soils (Ojanuga et al., 1996), but monitoring is necessary for understanding metal load (Odu et al., 1988) as elevated accumulation has direct consequences to man and ecosystem (Agbozu et al.,
2007) and crude oil spillage depends on type, ability and affordability of remediation techniques (Ram et al., 1993; Chu and Cha, 2003; Urum et al., 2005) chemical remediation techniques (Khattak and Page, 1992; Mench et al., 1994), phyto-remediation techniques (Lee and Chen, 1994; Brooks, 1998) and organic adsorbents (Stewart et al., 2003; Sekar et al., 2004; Carrasqueros et al., 2006; Gueu et al., 2007). Bioremediation techniques (King et al., 1997; NRC, 1993; Norris et al., 1993; Hinchee et al., 1995; Flathman et al., 1993). The paper objectives are impacts of the effects of hydrocarbon pollution soils nutrients; yield crops comments on agricultural crops critical nutrient concentrations and the solution to hydrocarbon degradation of soil nutrients of selected sites in the study area (Ogoniland) Niger Delta, Nigeria.

\section{MATERIALS AND METHODS}

\section{Study area}

In Ogoniland, the first discovery of petroleum was in Bomu field (1958), Korokoro (1962) and Yorla, Bodo West and Ebubu in the 1970s where explorations of all sites were without Environmental Impact Assessments (EIAs) reports with regulatory agencies. SPDC withdrew its entire staff from Ogoniland in January 1993 in the face of increasing intimidation and attacks from the host's communities (SPDC, 1995). SPDC operations are about two-thirds of the Niger Delta which covers over $20,000 \mathrm{~km}^{2}$. It is bounded by latitudes $4^{\circ} 20^{\prime} \mathrm{N}$ and $5^{\circ} 35^{\prime} \mathrm{N}$ and longitudes $5^{\circ} 30^{\prime} \mathrm{E}$ (Aprioku, 1999). SPDC and its joint venture partners, the Nigerian National Petroleum Corporation (NNPC), Elf and Agip have five major oilfields in the area with 96 wells looked up five flow stations in Bomu, Korokoro, Yorla, Bodo West and Ebubu (Figures 1 and 2).

The fields all date from the 1960s and 1970s and currently have a production potential of 28,000 barrels a day, about three percent of SPDC's crude production (SPDC, 1995) and the biggest challenges facing the degradation of the soil is oil exploration, (Aprioku, 1999). The Niger River enters Nigeria from the northwest, crossing the western part of the country to join the Atlantic Ocean in the South. Near the coast, the River forms this delta with mangrove forests, Lagoons, and Swamps stretching about 100km (about 60 miles) inland. The Niger Delta is the largest in Africa, covering an area of about 36,000 sq.km (about 14,000 sq. miles) (Figure 1).

There are unique difficulties in operating 86 flow-stations and about 6,200 kilometers of pipelines and flow-lines; and 31,000 square kilometers of the Niger Delta in a variety of extreme habitats including humid swamp forest, mangrove swamp, seasonallyflooded forest, (SPDC, 1995). From 1993 to October 1994, following the withdrawal of SPDC staff from Ogoni, there have been another 25 spills, 18 of which have been confirmed as sabotage, with another in Yorla site. SPDC has been using Ogoni contractors to clean up these spills since the beginning of 1993; all five of flowstations in the Ogoniland area have been vandalized (SPDC, 1995).

\section{Geology, geomorphology and drainage}

The geology of the study area is of sedimentary origin (Figure 1). They are deltaic in their formation being laid down by River Niger 


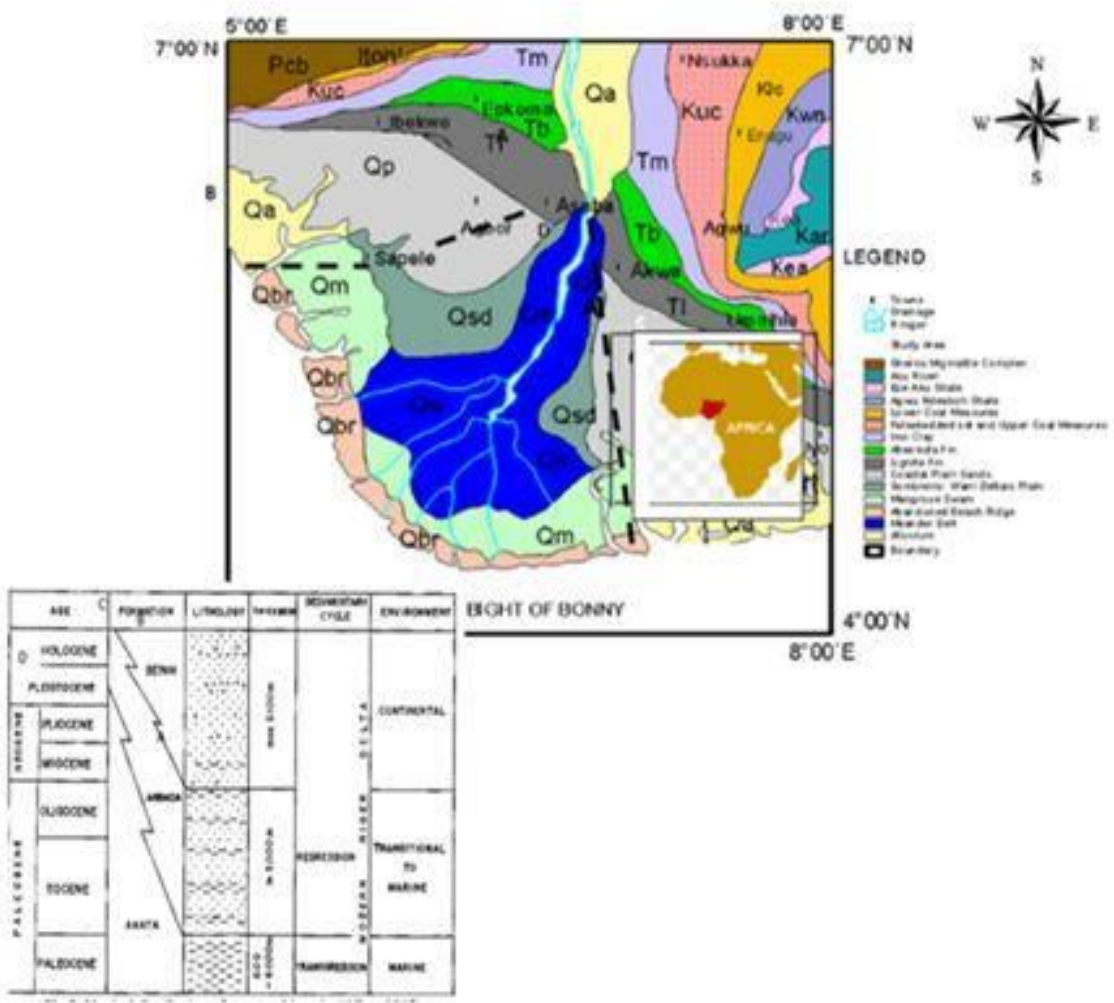

Figure 1. Geological map of southern Nigeria, showing the study area: Ogoniland, Niger Delta. Source: NGSA (1978), Allen (1965).

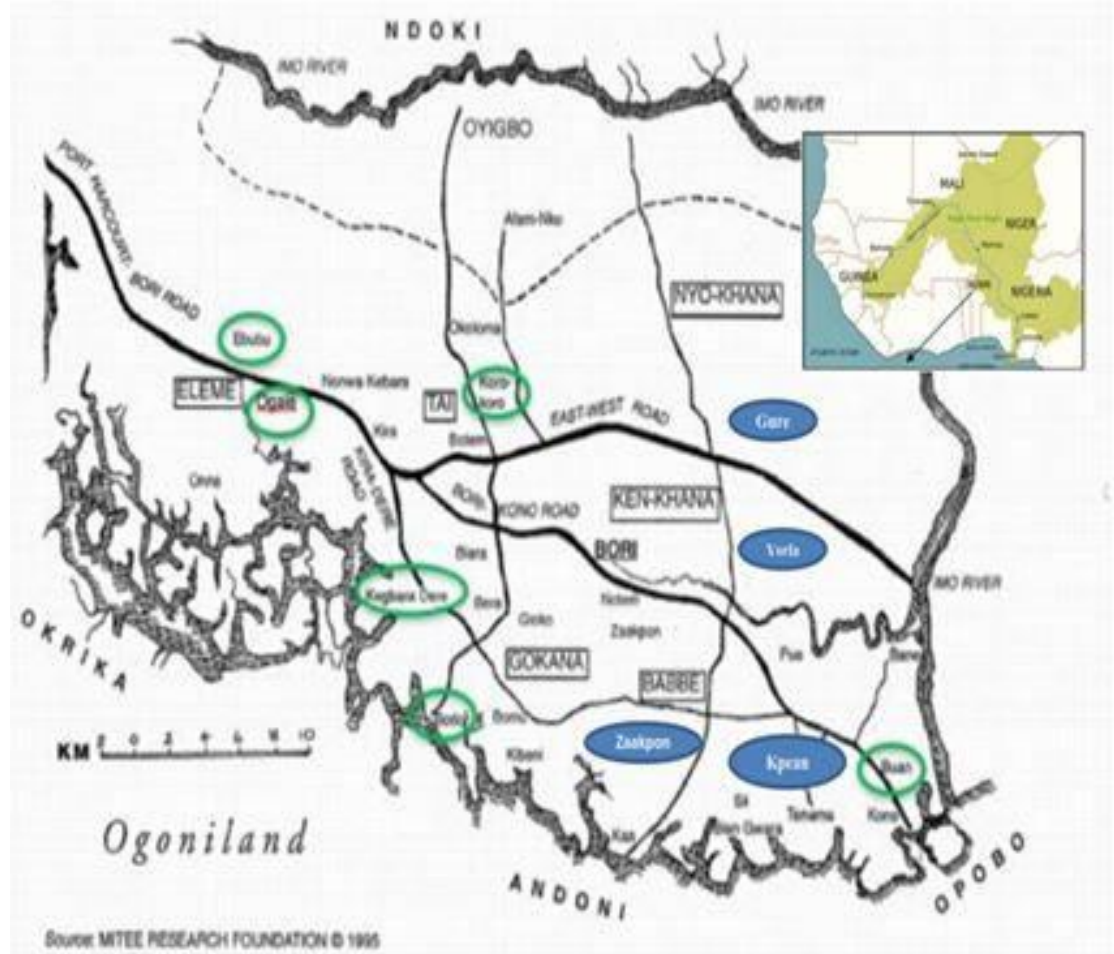

Figure 2. Geological map showing the study area locations Ogoniland (Gure, Kpean, Zaakpon and Yorla). Source: Mitee Research Foundation (C) (1995). 
during geological epochs. The subsurface geology of the Niger Delta consist of three lithographic units: Benin (Continental), Agbada (Mixed) and Akata (Marine) which are in turn overlain by various types of sedimentary deposits $(40$ to $150 \mathrm{~m})$ which generally consist of rapidly alternating sequences. The silt and clay, the quaternary rocks constitute various types of alluvium (Murat, 1972; Allen, 1965).

The Niger Delta Geomorphology has four units: The main drainage in the study area is River Niger and its tributaries. From 1 $\mathrm{km}$ in Agbere, the River breaks into two main branches: Forcados and Nun Rivers. These then form a very dense network of northsouth drainage systems. From below Burutu at the north of River Forcados to below Degema, a distance of about $150 \mathrm{~km}$, there are over fifty tributaries with a crises-cross of lagoons and tributaries (Murat, 1972) (Figure 1). The Niger Delta is one of the world's largest wetlands covering over $20,000 \mathrm{~km}^{2}$ in Southern Nigeria. A dynamic equilibrium between flooding, erosion and sediment deposition is the defining characteristic of the Niger Delta ecosystem (Aprioku and Berelueiso, 1996). The climate of the study area is the equatorial type. Generally, the temperatures are high throughout the year. There is a wet season lasting from April to October when the southwest winds dominate. The dry season in months of November to March also experiences rainfalls and sporadic rainstorms. Therefore, there is no month, where the mean annual rainfall is over $3600 \mathrm{~mm}$ with the highest occurring close to the south and decreasing north to about $300 \mathrm{~mm}$ (Ewuesie, 1998).

\section{Soils of the study area}

The soils of the study area varies and are complex due to the interplay of rock or geologic types, the hydromorphic nature of the soil, and rich climatic environment of excessive rainfalls. There are five major soils groups, they are: beach ridge soils, mangrove swamp soils, fresh water swamp soils, Sombreiro - Warri - Deltaic plain soils and coastal plain sands. The creeks and water channels of the coastlands form important fishing grounds and provide highways in this marshy area where road building is almost impossible (lloeje, 1976).

\section{Native soil nutrient}

The Niger Delta is a natural wetland, agro-ecology; nitrogen has been found to be the most limiting plant dynamics nutrient (Patrick and Deluance, 1976); because of competition between plant up take and biochemical processes function including freshwater marshes and hardwood swamp (Fetter et al., 1978; Zoltek et al., 1979) have been investigated. Upon flooding, the soil oxygen status is completely changed by mixing of water by wind action and convection currents (Reddy and Patrick, 1984) resulting to the removal of nitrogen from flooded soil, microbial activity and sediments. The redox potential at which oxygen disappears from the wetland soil system was found to be in the range of 320 to 340 Mv (Turner and Patrick, 1968). In a flooded mineral soil, approximately $50 \%$ of the total available oxygen is consumed in oxidizing the water-soluble ferrous iron which diffuses upwards from subsurface reduced zones (Howeler and Bouldin, 1971). The total oxygen consumption in a flooded soil was attributed to the oxidation of reduced iron and manganese, followed by oxygen consumption during the oxidation of organic carbon and ammonium nitrogen (Patrick and Reddy, 1976a).

\section{Soil nutrient type}

The Ogoniland soil of the study sites are classified as Ultisol (FAO/UNESCO, 1974). Ultisols are strongly acidic and highly leached upland soils occurring in the high rainfall region. They are coarse-textured, Kaolinitic type paleudults found in the coastal areas of the country and are derived mainly from coastal plain sands (Udo, 1973). Ultisols have a higher percentage of active Phosphorus (P) (38\%) and lower fraction of occluded P $(21 \%)$ than the Alfisols worth $22 \%$ of active $P$ and $35 \%$ of occluded $P$. This indicates that the Nigerian Ultisols have a higher fraction of total $P$ in the available form than the Alfisols (Udo, 1973). In a wetland system of the Niger Delta nitrification the surface-oxidized soil or sediment layer of the wetland systems, lake sediments or ocean muds (Curtis et al., 1975) and in the surface-oxidizing sediments (Reddy et al., 1980c). The gaseous forms of nitrogen that occur in flood soils and sediments include ammonia $\left(\mathrm{NH}_{3}\right)$, Dinitrogen $\left(\mathrm{N}_{2}\right)$ and nitrous oxide $\left(\mathrm{N}_{2} \mathrm{O}\right)$ (Reddy and Patrick, 1984).

\section{Agriculture}

The primary activity of many communities in Ogoniland is agriculture, $66 \%$ of households in the state are engaged in agricultural activities. According to the National Agricultural Sample Census 1993/94, 35\% of holdings on land are possessed on ownership tenure, $17 \%$ on rented land (FACU, 1993). Annual planting of staple crops starts in the dry season (November-March) when floodwater must have subsided. After clearing the of land, women and children plant maize, yam, cassava or vegetables and oil palm from both the wild environment and plantations. Crops that are usually planted include cassava, cocoyam, plantain, banana, maize, yam, rice, sugar cane, and groundnut and to a limited extent cash crops such as oil palm and rubber. In addition to the staple crops, high priced vegetables such Telfaira spp., Amaranthus spp., waterleaf, melon and sweet potato are use as cover crops. Newly cleared forests are utilized for plantain and banana to take advantage of high organic matter status. Various crop combinations of yam $/ \mathrm{melon} / \mathrm{maize} / \mathrm{cassava}$, plantain/cocoyam telfaira and maize are arranged in relay forms. Plantain may start bearing at 8 months, but it is allowed up to 4-5 years a piece while banana could stay longer, up to 7 years. Crop plants such as Citrus species, kola, guava, mangoes, plantain, pawpaw, pear and pineapple may be planted around homesteads and as avenues along pathways or boundaries of farms (World Bank, 1992).

The predominant method of maintaining soil fertility remains the age shifting cultivation and bush following systems which involve cropping the land for a length of fallow periods of 1-2 years. Land degradation and flooding constitute major constraints to agriculture in the freshwater forest zones of Ogoniland. As a result, agriculture is limited to areas with sufficiently short flooding periods to allow for a complete growing season (Dabibi, 1995).

\section{Soil sampling and analysis}

The depths of the bore on the polluted sites with hydrocarbon from pipeline breakage are $0-15 \mathrm{~cm}$ and $15-30 \mathrm{~cm}$ depths on each location (Table 2). The soils were air dried ground and sieved using a $1 \mathrm{~mm}$ nylon fibre sieved to remove rocks, roots and other large particles. Precautions were takes to avoid contamination during sampling, drying, grinding and storage. The $\mathrm{pH}$ water was measured (Hendershot and Lalande, 1993). Organic Carbon (Org C.) content was determined using the Walkley and Black (1934) Method. The total $\mathrm{N}$ in the soil was determined by the Micro-kjedahl digestion followed by distillation and titration (IITA, 1979). Available $P$ was determined using Mehlich -3 extracts. Exchangeable cation $\left(\mathrm{K}^{+}, \mathrm{Ca}^{++}, \mathrm{Mg}^{++}\right)$was determined by Mehlich -3 extracts. $\mathrm{K}^{+}$was determined by flame emission spectroscopy and $\mathrm{Ca}^{+}$and $\mathrm{Mg}^{+}$by atomic absorption spectroscopy (Anderson and Ingram, 1989). Heavy metals ( $\mathrm{Cu}, \mathrm{Zn}, \mathrm{Mn}$ and $\mathrm{Fe}$ ) analysis was determined using Mehlich-3 extracts Atomic adsorption spectrometer (AAS). 


\section{Statistical analysis}

All data set were subjected to statistical analysis as appropriate. Analysis of variance was conducted using the generated linear model (LLM) procedure to evaluate variance over locations, depths, macronutrients and micronutrients of the study areas. Mean separation was done using Duncan Multiple range test (SAS, 1985). Correlation and regression analysis were also conducted.

\section{RESULTS AND DISCUSSION}

The soil nutrient, plant nutrient and crop yield in crop production called critical plant nutrient concentration level or optimum concentration (De Saussure, 1804; Ulrich, 1949) which is just adequate for maximum growth (Tyner, 1947); and as the concentration above which sufficiency occurs (Jones, 1967). These techniques were used for a number of crops (Ulrich and Hills, 1967). The critical levels of nutrients were largely independent of the level of other factors (Macy, 1936). However, observed from the study areas, the critical levels will be influenced by several factors including the impacted effects of hydrocarbon on the selected communities' soil nutrients, Tables 1, 2 and 3 and Figures 3, 4, 5 and 6 respectively..

\section{Soil nutrients}

The agricultural systems in the humid tropics are being faced with rapid nutrient depletion because of the low chemical buffering capacity of the low activity clay soils (Kang and Wilson, 1987). Leaching processes are at their peak in humid tropical regions, where a predominance of clay minerals such as kaolin, gibbsite, haematite, and goethite can be observed. Local conditions particularly the enrichment of fresh rock that can occur at active plant boundaries (Fyfe et al., 1983).

\section{Macronutrients}

In the impacted study area as shown in the Table 1, the pH $4.30-5.20$ at $\mathrm{P}<0.01$ (LSD 0.38); Nitrogen oxide (No) $0.095-0.74 \mathrm{gkg}^{-1}$ at $\mathrm{P}<0.10$ (LSD 0.62; Potassium (K) $0.065-1.37 \mathrm{cmol} \mathrm{kg}^{-1}$ at $\mathrm{P}<0.01$ (LSD 0.027) has a significant relationship with the locations of the study area. The organic $C$ (Org. C) $10.56-20.2 \mathrm{gkg}^{-1}$ at $P<$ 0.10 (LSD 12.91); Ammonia (NH) $1.79-3.3 \mathrm{gkg}^{-1}$ at $\mathrm{P}<$ 0.10 (LSD 5.9); total nitrogen (total N) $2.54-5.97 \mathrm{mgkg}^{-1}$ $\mathrm{P}<0.10$ (LSD 6.23) and Available P 10.62 - $18.60 \mathrm{mgkg}^{-1}$ $P<0.10$ (LSD 9.47) had no significant relationship with the locations of the study area, Figure 3.

\section{Micronutrients}

In the impacted study area as shown in the Table 1, the Calcium (Ca) $0.95-1.34 \mathrm{cmol} \mathrm{kg}^{-1} \mathrm{P}<0.10$ (LSD 0.32) and Sodium (Na) $0.525-1.22 \mathrm{cmolkg}^{-1} \mathrm{P}<0.05$ (LSD 0.393 ) has a significant relationship with the locations of the study area. Magnesium (Mg) $0.232-0.313 \mathrm{cmolkg}^{-1} \mathrm{P}$ $<0.10$ (LSD 0.126) had no significant relationship with the locations of the study area, Figure 4 . Soil with a low organic matter content $(<1 \%$ organic carbon) will have low Available Water Capacity and organic carbon $>1.5 \%$ will have high AWC as shown in Table 3 and Zaakpon has the highest AWC. Soil formation of the study area constitutes garnet (anhydrous calcium-iron-magnesium silicate rich rock) and on weathering form silt, clay and sand (Sawkin et al., 1978). From Table 2, the location (Zaakpon) has the highest sand \% by particle size distribution relative to silt and clay. The $\mathrm{NO}_{3}{ }^{-} \mathrm{N}$ which accumulated at the commencement of the wet season appears to be lost mainly by leaching (Handy, 1946; Griffith, 1951), and to a lesser extent by denitrafication (Greenland, 1958).

\section{Heavy metals}

In the impacted study area as shown in Table 1, Manganese (Mn) $19.93-57.83$ ppm $P<0.10$ (LSD=37.5) and Iron $(\mathrm{Fe}) 180.4-508.4 \mathrm{ppm} \mathrm{P}<0.01(\mathrm{LSD}=161)$ has significant relationship with the locations of the study area. Copper $(\mathrm{Cu})$ 0.20-0.73 5ppm $\mathrm{P}<0.10(\mathrm{LSD}=0.337)$ and Zinc (Zn) 1.52-2.05 ppm P < 0.10 (LSD = 1.043) had no significant relationship with the locations of the study area.

The composition of the clay mineral fraction of soils irrespective of the particular climatic zone in which they occur. The distribution of organic matter in the tropical soil decreases with increasing (Agboola and Omueti, 1982). Jones (1973) found that the equilibrium organic matter content in Nigeria soils $(0$ to $15 \mathrm{~cm})$ under an established fallow of 1.03 percent from an initial value of up to 2 percent and organic carbon \% of the depth (0 to 16) $\mathrm{cm}$ is 1.37 and $10-36 \mathrm{~cm}$ is 0.41 to 0.50 (Moorman et al., 1981) confirms the study area data in Tables 2 and 3.Vegetation burn have dramatic effects biodiversity, encourages perennial grasses (Afolayan, 1978; Afolayan and Ajayi, 1979; Charreau, 1974). The organic carbon \% of the depth $(0-16) \mathrm{cm}$ is 1.37 and $10-36 \mathrm{~cm}$ is $0.41-0.50$ (Moorman et al., 1981; Enwezor and Moore, 1966) found organic $\mathrm{P}$ to be more than 40 percent of the Total $\mathrm{P}$. The generally low Total $P$ in these soils may be attributed to the low content in the parent materials from which these soils have been formed (Uzu et al., 1975; Ibedu, 1982). The distribution along the profile depth varies from soil to soil. Comparative effects of depths on impacted soils nutrients of selected sites (Ogoniland) locations was carried out using the general linear model of ANOVA (Analysis of Variance). The depths of the bore on the polluted sites with hydrocarbon from pipeline breakage with depths at 0 to $15 \mathrm{~cm}$ and 15 to $30 \mathrm{~cm}$ in the study area $(P<0.10)$ had significant impacts on soil nutrients, 
Table 1. The effects of hydrocarbon pollution on the soils and its chemical properties.

\begin{tabular}{|c|c|c|c|c|c|c|c|c|c|c|c|c|c|c|}
\hline Locations & $\mathrm{pH}$ & Org. C & NO & $\mathrm{NH}$ & Total N & Ava P & $\mathrm{Ca}$ & $\mathrm{Mg}$ & $\mathrm{K}$ & $\mathrm{Na}$ & $\mathrm{Cu}$ & Mn & $\mathrm{Zn}$ & $\mathrm{Fe}$ \\
\hline Units & & $\mathrm{g} / \mathrm{kg}$ & $\mathrm{Mg} / \mathrm{kg}$ & $\mathrm{Mg} / \mathrm{kg}$ & $\mathrm{Mg} / \mathrm{kg}$ & $\mathrm{Mg} / \mathrm{kg}$ & $\mathrm{Cmol} / \mathrm{kg}$ & $\mathrm{Cmol} / \mathrm{kg}$ & $\mathrm{Cmol} / \mathrm{kg}$ & $\mathrm{Cmol} / \mathrm{kg}$ & PPM & PPM & PPM & PPM \\
\hline Gure & 5.2 & 10.56 & 0.07 & 2.92 & 2.99 & 12.55 & 1.34 & 0.313 & 0.137 & 1.122 & 0.2 & 57.83 & 1.495 & 287.8 \\
\hline Zaakpon & 4.51 & 20.2 & 0.74 & 1.79 & 2.54 & 10.62 & 0.97 & 0.232 & 0.112 & 0.535 & 0.735 & 19.98 & 2.05 & 180.4 \\
\hline Yorla & 4.8 & 11.2 & 0.095 & 5.8 & 5.97 & 18.6 & 1.21 & 0.33 & 0.127 & 0.72 & 0.703 & 54.45 & 1.712 & 508.3 \\
\hline Kpean & 4.3 & 11.78 & 0.09 & 3.3 & 3.42 & 18.6 & 0.95 & 0.247 & 0.065 & 0.525 & 0.74 & 25.21 & 1.52 & 274.9 \\
\hline Level of S & $* * *$ & NS & * & NS & NS & NS & * & NS & $* * *$ & ** & NS & * & NS & $* * *$ \\
\hline LSD & 0.38 & 12.91 & 0.62 & 5.9 & 6.23 & 9.47 & 0.32 & 0.126 & $0 . .027$ & 0.393 & 0.337 & 37.5 & 1.043 & 161 \\
\hline
\end{tabular}

Note: 1. LSD $=$ Least Significant Difference $(0.05) ; 2 .{ }^{*}=$ Significant at $P<0.10 ; 3 .{ }^{* *}=$ Significant at $P<0.05 ; 4 .{ }^{* \star}=$ Significant at $P<0.01 ; 5$. NS $=$ Not significant at $P<0.1$.

Table 2. Particle size distribution of the soils of the experimental locations.

\begin{tabular}{|c|c|c|c|c|c|c|c|}
\hline \multirow{2}{*}{ Locations } & & \multicolumn{3}{|c|}{$0-15 \mathrm{~cm}$} & \multicolumn{3}{|c|}{$15-30 \mathrm{~cm}$} \\
\hline & & Sand (\%) & Silt (\%) & Clay (\%) & Sand (\%) & Silt (\%) & Clay (\%) \\
\hline \multirow{2}{*}{ Gure } & Non-polluted & 64 & 26 & 10 & 62 & 34 & 4 \\
\hline & Polluted & 64 & 26 & 10 & 64 & 32 & 4 \\
\hline \multirow{2}{*}{ Zaakpon } & Non-polluted & 80 & 10 & 10 & 70 & 22 & 8 \\
\hline & Polluted & 69.30 & 20.70 & 10 & 73.30 & 24 & 6 \\
\hline \multirow{2}{*}{ Kpean } & Non-polluted & 82 & 12 & 6 & 79 & 15 & 6 \\
\hline & Polluted & 77.10 & 14.20 & 8.70 & 77.70 & 24 & 5.30 \\
\hline \multirow{2}{*}{ Yorla } & Non-polluted & 67 & 25 & 8 & 67 & 24 & 8 \\
\hline & Polluted & 75.40 & 17.10 & 7.60 & 75.70 & 16.30 & 8 \\
\hline
\end{tabular}

Table 3. Organic carbon \% (Org. C \%) of the study area.

\begin{tabular}{lcc}
\hline Locations & Native soils (unpolluted) & Impacted soils (Polluted) \\
\hline Gure & 0.253 & 1.224 \\
Zaakpon & 0.644 & 2.139 \\
Kpean & 1.297 & 1.181 \\
Yorla & 1.691 & 1.15 \\
\hline
\end{tabular}



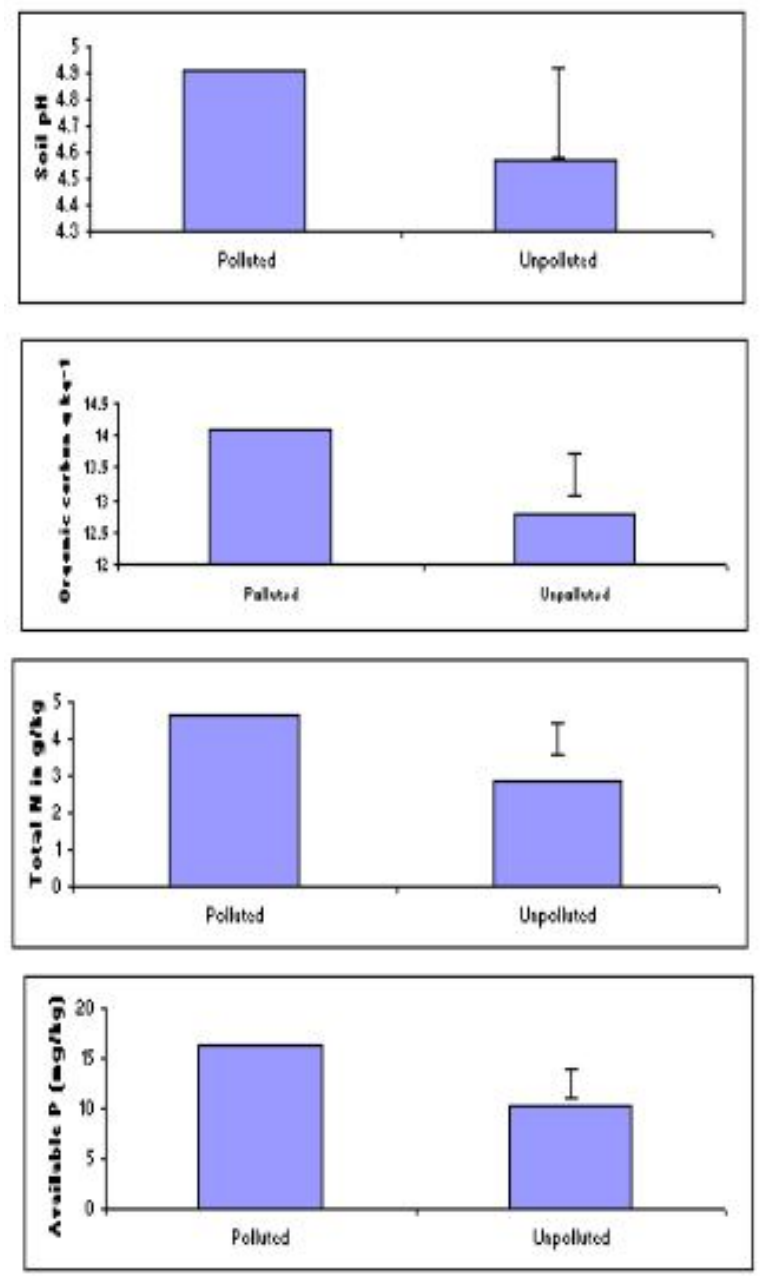

Figure 3. Comparative effects of hydrocarbon pollution on the soils $\mathrm{pH}$, organic carbon, total nitrogen and available phosphorus on the study area. Bars represent Standard Error (SE).

Table 2.

\section{Exchangeable cations}

The multiple regressions analysis of Cations shows $\mathrm{R} 2=$ $0.8524(P<0.05)$ had significant relationship on depth $(0$ to $15 \mathrm{~cm}$ ) of the study location only. Within the depths of 15 to $30 \mathrm{~cm}$, no exchangeable cations had significant relationship with depths of the locations in Table 1.

A large range of microbial genera have been reported to degrade hydrocarbons (Atlas, 1981; Rosenberg, 1992); broad spectrum of genera (Kampfer et al., 1991); toxic to bacterial membranes (Sikkema et al., 1995) and contaminated soil is often poor in organic matter and has a general low microbial activity. Bioaugumented microbial inocula is required for the soil in the study areas for soil bioremediation of the polluted sites. Table 3 high $\mathrm{C} / \mathrm{N}$ ratio of the impacted soils in the study area by
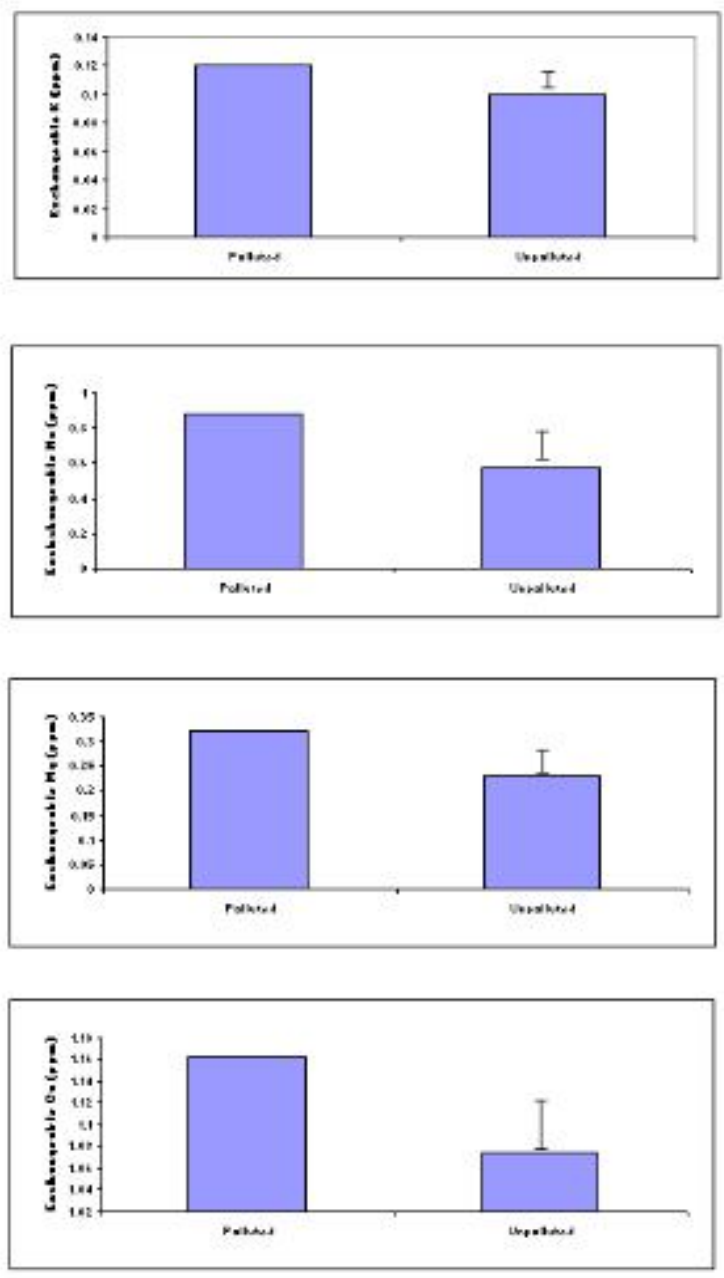

Figure 4. Comparative effects of hydrocarbon pollution on the soil exchangeable cations at some selected sites in Ogoniland. Bars represent SE.

hydrocarbon pollution Gure (11.58), Zaakpon (52.92) and Kpean (25.49) will requires soils augmentation to improves the microbial activity for bioremediation and restoration ecology. Yorla with $\mathrm{C} / \mathrm{N}$ ratio will enhance bioremediation activates and re-vegetation with energy crops (maize, etcs).

\section{Agro-ecology}

They influence the system and intensity of cropping, the need for fallowing, the species and varieties of crops that can be grown and the risk of drought stress (Mutsaers et al., 1997). The FAO soil classification of the study area is Ultisols, mainly humid climates and less stable landscapes; also, coarse to medium surface layer, exchange base saturation $<50 \%$ and generally acidic $(\mathrm{pH}<5)$. The fertility capability soil classification (FCC) (Buol and Couto, 1981; Sanchez and Salinas, 1982; Lal, 1979; Mansfield, 1979; Greenland, 1958) provides 

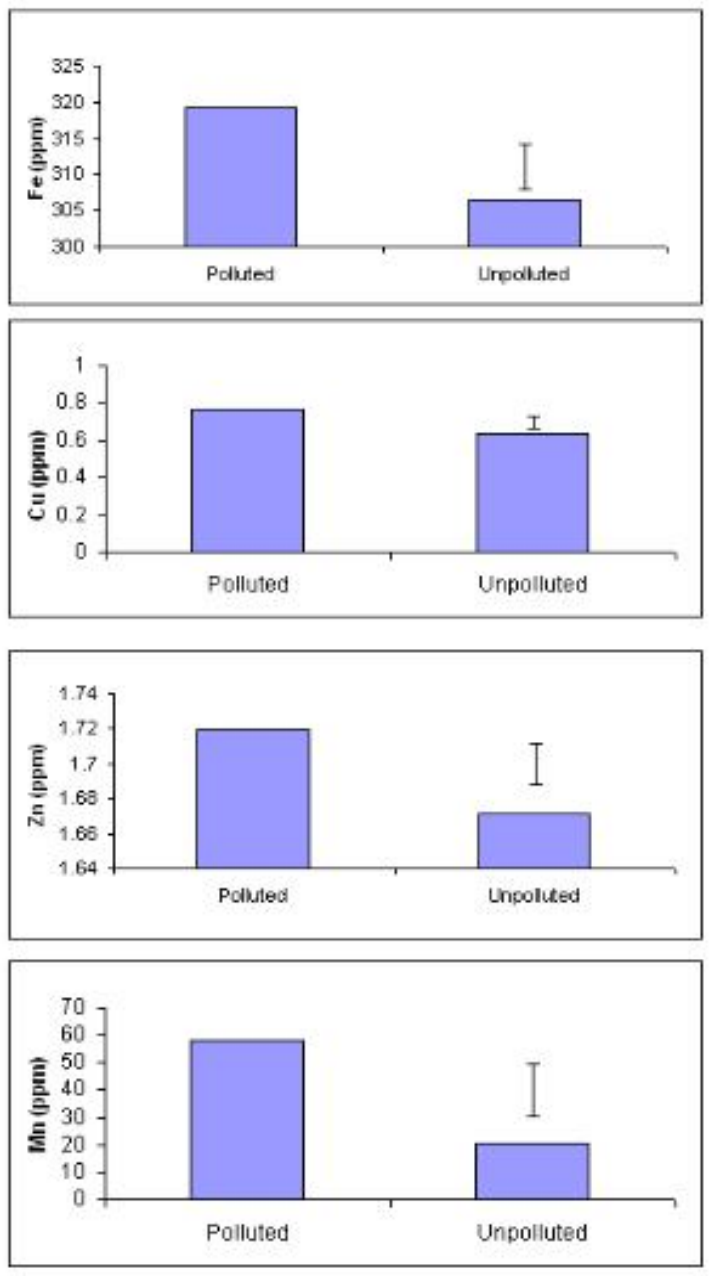

Figure 5. Effects of pollution on plant essentials heavy metals in selected communities in the study area.

explanations based on data on Tables 1, 2 and 3.

\section{Critical nutrient concentrations}

An interesting alterative to chemical soil analysis for the measurement of initial soil fertility is the use of maize as an indication plant (Osiname et al., 1991; Eilitta et al., 1991). Toxic concentrations of a nutrient in the specified plant part are usually associated with symptoms of toxicity or reduced growth and production and severely reduced quality or excessive vigor (Reuter and Robinson, 1986) and could be a useful diagnostic tool for soil amendment in crop production in the study area based on restoration ecology of the remediated polluted Ogoniland landscape. Selected crops in the study areas are:

\section{A. Maize (Zea Mays):}

The chemical properties of impacted soils show from Table 1 that the $\mathrm{pH}(4.3-5.2)$ is highly acidic and
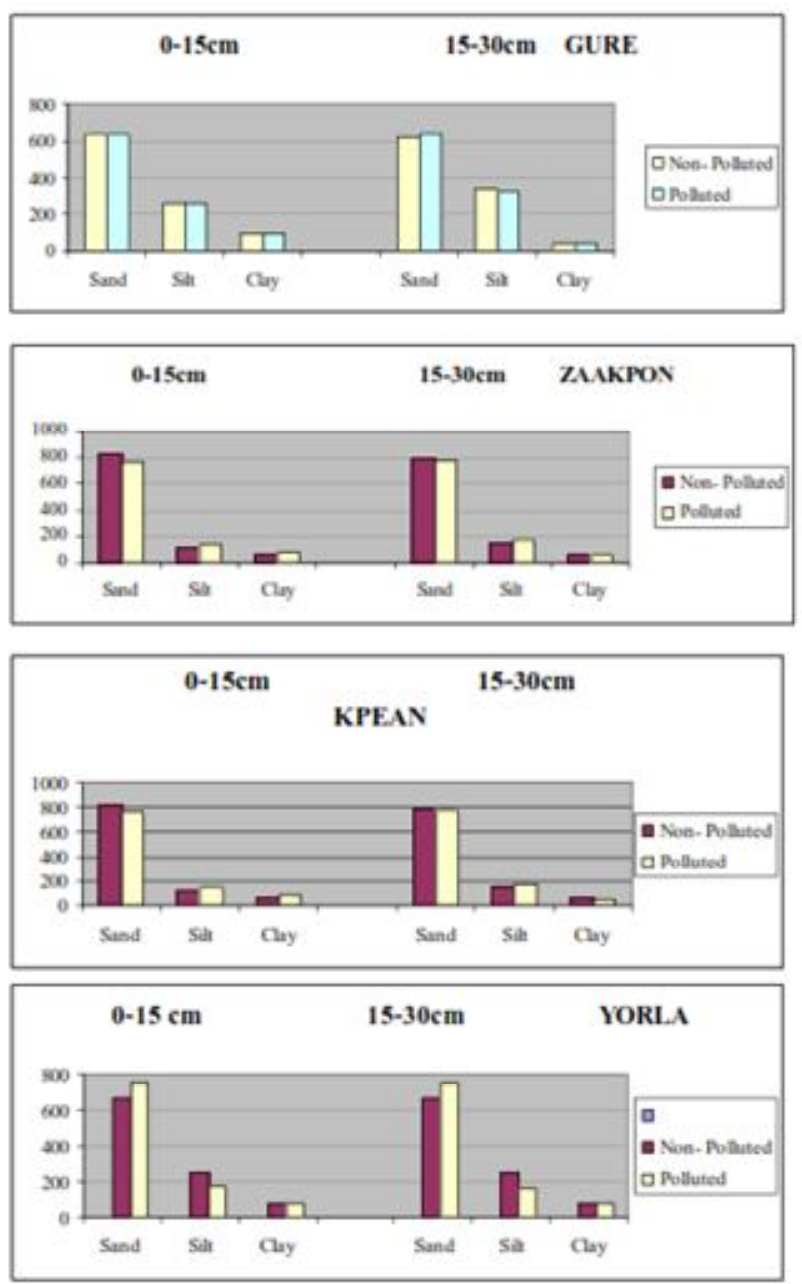

Figure 6. The hydrocarbon pollution effects on the particle size distribution of the study area.

requiring liming in all locations of the study area. The critical range of $\mathrm{pH}$ for maize production is 6 to 6.5 (Adeoye and Agboola, 1985). Organic Carbon (Org. C) content of the impacted soil decreases with depths. The total $\mathrm{N}$ for the impacted soils range from 0.58 to $0.179 \%$, showing that the soils requires Urea to improve the nitrogen (total $\mathrm{N}$ ) to the adequate concentration $3.0 \% \mathrm{~N}$ for maize production (Hanway, 1962). The available $\mathrm{P}$ of the impacted soils range 10.62 to $18.60 \mathrm{mgkg}^{-1}$, the critical concentration requirement of Ava. $P$ (10 to 16 $\mathrm{mgkg}^{-1}$ ) for maize production (Adeoye and Agboola, 1985) showing that remediated and fortified impacted soils will support maize growth/production. The Exch K of impacted soils range is 0.025 to $0.053 \%$. The critical nutrient concentration is 0.234 to $0.312 \%$ as posited by Adeoye and Agboola (1985). Mg\% range from 0.232 to $0.33 \mathrm{cmolkg}^{-1}(0.056-0.075 \%)$ as stated by Weir (1983).

For maize production Fe>350 $\mathrm{mgkg}^{-1}$ is toxic (Jones, 1967). The critical range is 50 to $300 \mathrm{mgkg}^{-1}$ for maize (Lockman, 1969). It shows that locations (Gure, Zaakpon 
and Kpean) when remediated and fortified with mineral nutrients could adequately support maize production. Yorla location is highly toxic to maize production. The critical range value is $0.4 \% \mathrm{Ca}$ for maize production (Melsted et al., 1969).

Impacted soils when remediated and fortified will support maize cultivation.

\section{B. Banana (Musa spp.):}

The chemical properties of impacted soils form the Table 1 show that $\mathrm{K} \mathrm{cmolkg}^{-1}$ ranges from 0.025 to $0.053 \%$. $\mathrm{K}<$ $2.5 \%$ is deficiency (Reuter and Robinson, 1986). Ava P $\%$ in the impacted soil range $(0.125-0.186)$ The $\mathrm{P} \%$ marginal concentration range is 0.13 to 0.19 (Rueter et al., 1986) for Banana production. It shows that when impacted soil is remediated and fortified, it could support banana production. The chemical properties of impacted soils show that Mg\% $0.056-0.075 \%$ form the Table 1 . The $\mathrm{Mg}<0.2 \%$ shows deficiency for Banana production (Reuter and Robinson, 1986). The $\mathrm{Na}(\%)$ of the impacted soils shows 0.121 to $0.260 \%$. The adequate concentration range for concentration for maize production is $0.25 \mathrm{mg} \%$. Hence, this shows that it is deficient. The $\mathrm{Ca}$ Content of the impacted soils ranges from 0.95 to $1.34 \mathrm{cmolkg}^{-1}(0.38-0.554 \%)$.

$\mathrm{Zn}(20-50) \mathrm{mgkg}^{-1}$ is adequate for maize production (Lockman, 1969). The impacted soils $\mathrm{Mn}$ range from 19.98 to 57.83 ppm or $\mathrm{mgkg}^{-1}$ (Adeoye and Agboola, 1985). The Cu mgkg ${ }^{-1}$ value critical concentration is 9 $\mathrm{mgkg}^{-1}$ (Reuter and Robinson, 1986); and shows deficiency in $\mathrm{Cu}$ soil nutrient. Fe (Iron) $\mathrm{mgkg}^{-1}$ in the impacted soil range is 70 to 200 for Banana production (Reuter and Robinson, 1986). Hence, remediated and fortified impacted soils will support banana production.

\section{Cassava (Manihot esculenta):}

The impacted soils from Table 3 show $\mathrm{pH}$ (4.3 to 5.2), highly acidic and requiring liming and organic carbon 10.56 to $20.2 \mathrm{mgkg}^{-1}$ range in the study area. The total $\mathrm{N}$ for the impacted soils range (0.58 to $0.179 \%)$. The concentration range for $\mathrm{N} \%$ was $<4.5$ for deficient by Howeler (1978). Hence, the impacted soils need remediation and fortification with urea. The available $\mathrm{P}$ of the impacted soils ranges from 0.011 to $0.019 \%$. The critical concentration for deficiency is $P<0.2 \%$ for cassava growth (Howeler, 1978). The Exch K of the impacted soils ranges from 0.025 to $0.053 \%$. The critical concentration for deficiency $\mathrm{K}$ is $0.43 \%$ (Patterson, 1985). $\mathrm{Mg}$ of the impacted soils ranged from 0.056 to $0.075 \%$ (Table 1). The critical concentration for deficiency is $<0.29 \% \mathrm{Mg}$ (Asher et al., 1980). Ca of impacted soils ranges from 0.38 to $0.54 \%$. The critical concentration for deficiency is $\mathrm{Ca}<0.5 \%$ (Howeler, 1978). Impacted soils $\mathrm{Zn}$ range between 1.495 and $2.05 \mathrm{ppm}$ or $\mathrm{mgkg}^{-1}$. The critical concentration for deficiency of $\mathrm{Zn}$ is $<35 \mathrm{mgkg}^{-1}$ for cassava (Howeler, 1978). The impacted soils Mn ranges from 19.98 to $57.83 \mathrm{ppm}$ (Table 1). The critical concentration for deficiency is $\mathrm{Mn}<50 \mathrm{mgkg}^{-1}$. Cu ranges from 0.20 to $0.74 \mathrm{ppm}$ for impacted soils. The critical range concentration is $6 \mathrm{mgkg}^{-1}$ (Howeler, 1983). $\mathrm{Fe}$ (Iron) value for impacted soil is $180.4 \mathrm{ppm}$. The critical concentration for $\mathrm{Fe}$ is 60 to $200 \mathrm{mgkg}^{-1}$ and $>250 \mathrm{mgkg}$ ${ }^{1}$ (Howeler, 1982). It shows that Gure, Yorla and Kpean impacted soils is very toxic for cassava production. When remediated and fortified will support cassava growth.

\section{Mango (Mangifera indica):}

The total $\mathrm{N}$ for the impacted soils ranges from 0.58 to $0.18 \%$ in Table 1 . The adequate concentration of $\mathrm{N} \%$ is 1.0 to 1.5 for mango growth (Reuter and Robinson, 1986). The Exch $K$ of the impacted soils ranges from 0.025 to $0.053 \%$ and the critical concentration for deficient for $\mathrm{K}$ is $<0.25 \%$. The Ava $\mathrm{P}$ of the impacted soils range from 0.011 to $0.019 \%$. The adequate concentration is between 0.08 and $0.18 \%$ (Reuter and Robinson, 1986). Impacted soils $\mathrm{Mg}$ range between 0.056 to $0.075 \%$. The adequate concentration for $\mathrm{Mg}$ is between 0.2 and $0.4 \%$. The $\mathrm{Ca}$ value of impacted soils ranges from 0.38 to $0.54 \%$. The adequate concentration ranges from 2.0 to $3.5 \%$ for acidic soil and 3.0 to 5.0 for alkaline soil. The impacted soil $\mathrm{Na}$ ranges from 0.121 to $0.258 \%$ and the adequate concentration is $\mathrm{Na}<0.2 \%$ (Reuter and Robinson, 1986). Impacted soils $\mathrm{Zn}$ range from 1.495 to $2.05 \mathrm{ppm}$ or $\mathrm{mgkg}^{-1}$. The critical concentration for deficiency is $<15 \mathrm{mgkg}^{-1}$. The impacted soils $\mathrm{Mn}$ ranges from 19.98 to $57.83 \mathrm{mgkg}^{-1}$. Cu ranges from 0.20 to 0.74 $\mathrm{mgkg}^{-1}$ for impacted soils. The adequate concentration ranges from 10 to $20 \mathrm{mgkg}^{-1}$ for $\mathrm{Cu}$ (Reuter and Robinson, 1986). Fe value for Zaakpon was $180.4 \mathrm{mgkg}^{-1}$ for impacted soil. The adequate concentration for Iron $(\mathrm{Fe})$ is 70 to $200 \mathrm{mg} \mathrm{kg}^{-1}$ (Reuter and Robinson, 1986). The Yorla, Kpean and Gure are very toxic in impacted soil Fe content. It will require remediation and fortification to support mango growth. When impacted soils remediated and fortified by mineral nutrients, they will support mango growth.

\section{E. Pineapple (Ananas comosus):}

The total $\mathrm{N}$ for the impacted soils ranges from 0.58 to $0.179 \%$. The concentration value for $\mathrm{N}$ is $1.4 \%$ for pineapple deficiency growth. The available $\mathrm{P}$ of impacted soils ranges from 0.01 to $0.019 \%$. The concentration deficient value is $\mathrm{P}<0.13 \%$. The Exch $\mathrm{K}$ of the impacted soils range $0.025-0.053 \%$. The concentration deficient value is $\mathrm{P}<2.8 \%$ (Reuter and Robinson, 1986). Hence, the impacted soils when remediated and fortified with mineral nutrient will support pineapple growth. The $\mathrm{pH}$ of 4.3 to 5.2 shows acidic. Mg. is 0.056 to $0.078 \%$ for impacted soils. The concentration for deficiency is $\mathrm{P}<$ $0.13 \% \mathrm{Ca}(0.38$ to $0.54 \%)$ of the impacted soils. The concentration for deficiency of $\mathrm{Ca}$ is $<0.04 \%$. The $\mathrm{Na} \%$ for impacted soil is 0.123 to $0.256 \%$. The adequate 
concentration for $\mathrm{Na}$ is 0.004 to $0.015 \%$ (Reuter and Robinson, 1986). Impacted soils $\mathrm{Zn}$ range from 1.50 to $2.05 \mathrm{mgkg}^{-1}$. The adequate concentration range from 15 to $70 \mathrm{mgkg}^{-1}$. The impacted soils $\mathrm{mg}$ range from 19.98 to $57.83 \mathrm{mgkg}^{-1}$ and the adequate concentration value range from 150 to $400 \mathrm{mgkg}^{-1}$. Cu range from 0.20 to $0.74 \mathrm{mgkg}^{-1}$ for impacted soils; and the adequate concentration range from 10 to $50 \mathrm{mgkg}^{-1}$ (Reuter and Robinson, 1986). Fe (Iron) value for Zaakpon is 180.4 $\mathrm{mgkg}^{-1}(\mathrm{ppm})$ in the impacted soil. The adequate concentration for $\mathrm{Fe}$ is 80 to $150 \mathrm{mgkg}^{-1}$ (Reuter and Robinson, 1986). The locations (Yorla, Kpean and Gure) are very toxic Iron (Fe) with $\left(\mathrm{Fe}>150 \mathrm{mgkg}^{-1}\right)$. Remediation of impacted soil and fortification will support pineapple growth. Remediation of impacted soil and fortification will support pineapple growth.

\section{F. Sweet potato (Solanum tuberosum):}

The organic carbon of the impacted soils in the study area is of no significance and the soil pH (4.3 to 5.2) is acidic which requires liming. The total $\mathrm{N}$ from the impacted soil range $0.58-0.179 \%$. The nutrients concentration level for deficiency is $\mathrm{N}<2.0 \%$ (Purseglove,1992; Woolfe,1992). The available P in the impacted soils is $0.011-0.019 \%$. The nutrients concentration level for deficiency is $\mathrm{P}<0.20 \%$ (Troug et al., 1953). The Exch $\mathrm{K}$ of the impacted soils ranges from 0.025 to $0.053 \%$. The nutrient concentration level for adequate $\mathrm{K}$ is 3.5 to $5.0 \%$ (Moorthy,2002; Sindi, 2015). $\mathrm{Mg}$ of the impacted soils ranges from 0.056 to $0.075 \%$. The nutrient concentration level for deficiency is $\mathrm{Mg}<0.35 \%$ (Hahn, 1977). Ca is $0.38-0.54 \%$ of impacted soils. The critical concentration nutrient level $\mathrm{Ca}$ is $0.8 \%$ for sweet potato (Piggott, 1972).

The $\mathrm{Na}$ is 0.12 to $0.26 \%$ for impacted soils. The adequate concentration nutrient level $\mathrm{Na}$ is 0.05 to $0.50 \%$ (Peverill, 1993). Impacted soils $\mathrm{Zn}$ ranges from 1.5 to $2.05 \mathrm{mgkg}^{-1}$. The nutrient concentration level for deficiency $\mathrm{Zn}$ is $<10 \mathrm{mgkg}^{-1}$ (Lakanen and Erviò, 1971). The $\mathrm{Mn}$ is 19.98 - $57.83 \mathrm{mgkg}^{-1}$ for impacted soils. The nutrient concentration level for deficient $\mathrm{Mn}$ is $<20 \mathrm{mgkg}^{-1}$ (Weir, 1983). Cu ranges from 0.20 to $0.74 \mathrm{mgkg}^{-1}$ for impacted soils. The $\mathrm{Cu}$ nutrient concentration level for deficient $\mathrm{Cu}$ is $<8 \mathrm{mgkg}^{-1}$ (Gupta, 1983). Fe (Iron) is $180.4 \mathrm{mgkg}^{-1}$ for Zaakpon (impacted soils). The nutrient concentration level adequate for potato is between 70 and $150 \mathrm{mgkg}^{-1}$ (Walsh et al., 1973). The locations (Gure, Yorla and Kpean) impacted soils are very toxic for potato growth. The impacted soils require remediation and mineral fortification to grow sweet potato.

\section{G. Tomato:}

The total $\mathrm{N}$ is 0.58 to $0.18 \%$ for impacted soils. The nutrient concentration level for $\mathrm{N}$ is $<2.60 \%$ for deficient for tomato (Wooley, 1957). The Exch K ranges for 0.025 to $0.053 \%$. The nutrient concentration level for $\mathrm{K} 0.9 \%$ required for marginal growth (Benton, 2003). The Ava $P$ $(0.011$ to $0.019 \%)$ impacted soils. The deficiency in nutrient concentration $P$ was 0.10 to $0.35 \%$ level for tomato (Marschner,1995; Le Mare, 1981). Impacted soils remediated and fortified by mineral nutrients will support tomatoes growth. The $\mathrm{pH}$ of the impacted soils is 4.3 to 5.2 , which is very acidic, therefore requiring liming. $\mathrm{Mg}$ ranges from 0.056 to $0.075 \%$ for the impacted soils. The critical nutrient concentration required $\mathrm{mg} 0.1 \%$ for tomato (Peverill,1993; Peverill et al.,1999). Ca is 0.38 to $0.54 \%$ for impacted soils. The nutrient concentration level for deficiency is $0.58-1.30 \% \mathrm{Ca}$ (Geering and Hodson, 1969). The Na $0.121-2.0 .258 \%$ for impacted soils and high concentration of nutrient required $\mathrm{Na} 0.4 \%$ (Barke, 1984). Zn ranges from 1.5 to $2.05 \mathrm{mgkg}^{-1}$ for impacted soils. The nutrient concentration level for deficient $\mathrm{Zn}$ is $<20 \%$ (Barke, 1984). $\mathrm{Mn}$ in the impacted soils $(0$ to $3 \mathrm{~cm})$ depth of clay content $(<20 \%)$ is poor with medium infiltration rate, and medium water-holding capacity. The agricultural systems in the humid tropics are being faced with rapid nutrient depletion because of the low chemical buffering capacity of the low activity clay soils (Kang and Wilson, 1987). Furthermore, continuous use of nitrogen $(\mathrm{N})$ fertilizer can result in soil acidification (Jones and Wild, 1975). Systemic approaches for the management of soil fertility are therefore necessary. Most plants and soil microorganism thrive best in soils of $\mathrm{pH} 6$ to 7.5. The soil $\mathrm{pH}$ of impacted soil range (4.3-5.2) requiring soil amendment for agriculture purposes. The impacted soils fertility analyses (selected crops required to be grown) to improve the polluted ecosystem and correct the imbalance in the agro-ecology by practicing the farming system with the following crops: maize, banana, cassava, mango, pineapple, sweet potato and tomatoes base on their critical nutrient concentrations of crops yield (19.98 to 57.83 ) $\mathrm{mgkg}^{-1}$ for impacted soils. The nutrient concentration required for deficiency $\mathrm{Mn}<25$ $\mathrm{mgkg}^{-1}$ (Barke, 1984). Cu ranged from 0.20 to $0.74 \mathrm{mgkg}$ 1 for impacted soils. The nutrient concentration level adequate for growth is Cu $5.15 \mathrm{mgkg}^{-1}$ (Barke, 1984). Fe is 180.4 - $274.9 \mathrm{mgkg}^{-1}$ for impacted soil for Gure, Zaakpon and Kpean. The nutrient concentration level adequate is 100 to $300 \mathrm{mgkg}^{-1}$ (Barke, 1984). The Yorla impacted soils (508. $3 \mathrm{mgkg}^{-1}$ ) is very toxic to tomatoes growth. Remediation and mineral fortification is required for soil improvement to support tomato growth.

\section{CONCLUSION}

Oil spill destroys useful farmland and pollutes fishing creeks. Fish kill is common in waters polluted by hydrocarbon (Figure 7). This depletes fish population and other aquatic life. Besides, heavy machinery used in oil prospecting and mining destroys vegetation, devastates the land and renders the land unsuitable for farming. The soil is rendered infertile by oil (Figure 7). Residents of these areas suffer untold hardship to obtain freshwater. 

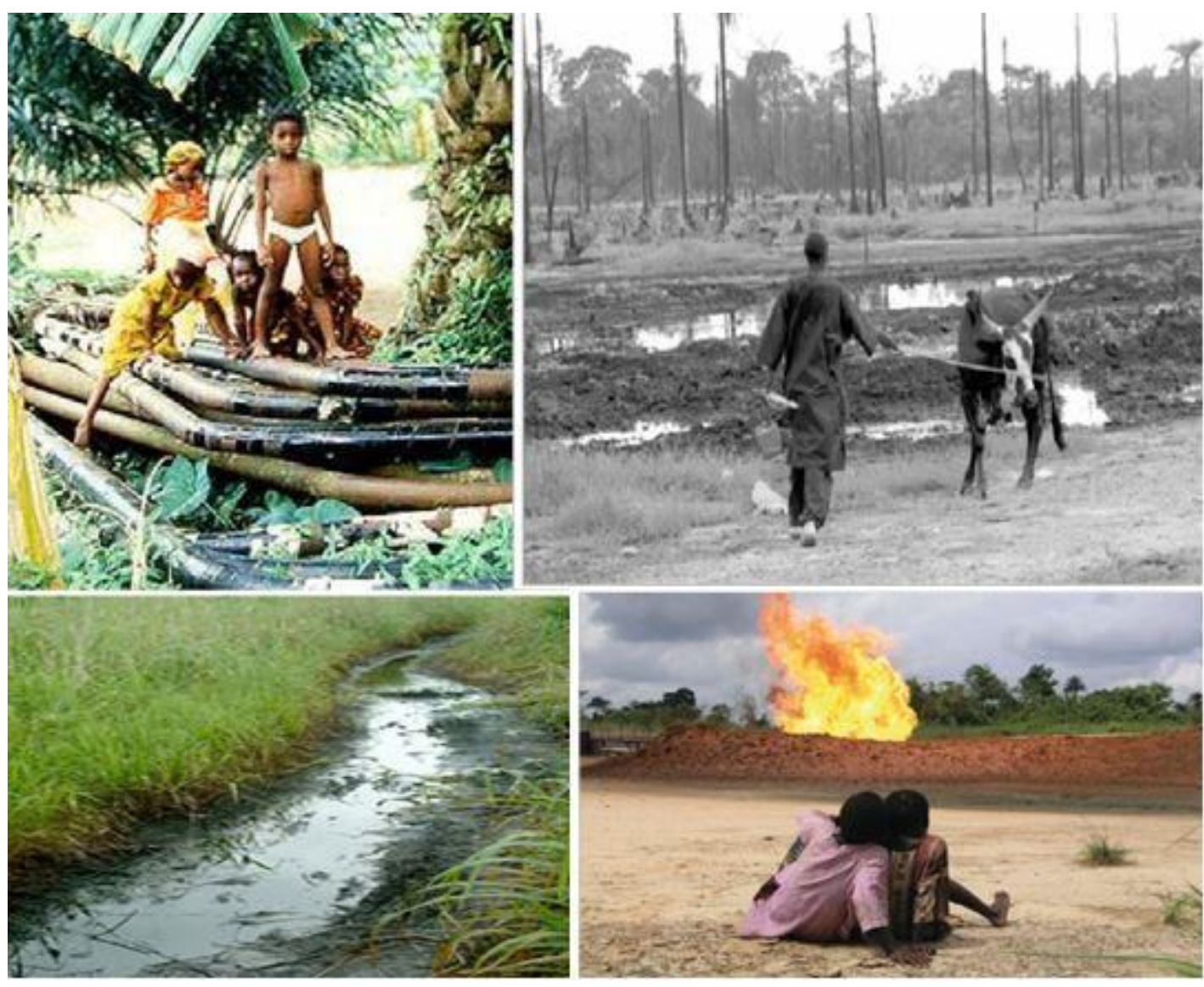

Figure 7. Impacts of hydrocarbon exploration on the ecosystems in Niger Delta, Nigeria.

This truncates the indigenous economy of the people leaving them impoverished. Consequently, the area is prone to acid rain. Forest ecosystems react sensitively to the mangrove soils are highly acidic with $\mathrm{pH}$ value as high as 2.8. In the study areas, communities of Ogoniland, the average $\mathrm{pH}$ is 5.1. The aesthetic and environmental quality of the oil production zone is impaired. The impacts of hydrocarbon toxic effects have been found to be generally localized between 0 and 15 $\mathrm{cm}$ depth of the impacted soils with low organic matter content $(<1 \%$ organic carbon) and invariable low available water content (AWC) in $\mathrm{mm} / 50 \mathrm{~cm}$ and shows little humus and own their red yellow colours to the oxide of iron at subsurface $(0$ to $15 \mathrm{~cm}$ ). Zaakpon (organic $\mathrm{C}>1.5 \%$ ) have high AWC with the highest sand \%by particle size distribution relative to silt and clay.

Safety is paramount in the industry. Safety precautions should always be taken by industry personnel to prevent accidents in all oil production counties in Niger Delta. A strong legislation against pollution of the environment is required. The legislation should include the "Polluter Pay" principle. Perhaps, it is only in Nigeria that the environment is devastated and abandoned by the multinational oil companies and regular maintenance of oil pipeline (Figure 7).

\section{REFERENCES}

Abe F, Ayodele A, 1983. Oil exploration, drilling and the environment, paper presented at the National Conference on Development and the Environment, NISER (Ibadan), Nigeria.

Adeoye GO, Agboola AA, 1985. Critical levels for soil $\mathrm{pH}$, available $\mathrm{P}$, $\mathrm{K}, \mathrm{Zn}$ and $\mathrm{Mn}$ and maize ear-leaf content of $\mathrm{P}, \mathrm{Cu}$ and $\mathrm{Mn}$ in sedimentary soils of Western Nigeria. Fertilizer Research, 6: 65-71.

Afolayan TA, 1978. The effect of fires and the vegetation in Kainji Lake National park, Nigeria. Oikos, 31: 376-382.

Afolayan TA, Ajayi SS, 1979. Reasons for further burning experiments in West African Savannah woodland. Commonwealth Forestry Rev, 58: 253-265.

Agboola AA, Omueti JAI, 1982. Soil fertility problems and its management in tropical Africa. In Int. Conf. on Land Clearing and Develop Proceedings Vol.2, I.I.T.A., Ibadan, Nigeria.

Agbozu IE, Ekweozor IKE, Opuene K, 2007. Survey of heavy metals in the catfish Synodontic claries. I J Environ Sci Technol, 4(1): 93-7.

Aiyesanmi AF, 2005. Assessment of heavy metal contamination of Robertkiri oil field's soil. Nig J Soil Sci, $15: 42-6$.

Akamigbo FOR, Jidere CM, 2002.Carbon nitrogen dynamics in organic wastes amended crude oil polluted wetland soi1. Agro-Science; 3(1): $20-6$.

Allen JRL, 1965. Late Quatenary Niger Delta and adjacent areas: sedimentary environment and lithofacies. American Association of Petroleum Geologists, Vol. 49, pp. 549-600.

Alvarez $\mathrm{P}$, Anid PJ, Vogel M, 1991. Kinetics of aerobic biodegradation of benzene and toluene in sandy aquifer material. Biodegradation. 2 : 43-51.

Aprioku IM, 1999. Collected response to oil spill hazards in the Eastern 
Niger Delta of Niger Delta of Nigeria. J Environ Planning Manag, 42(3): 389-408.

Aprioku IM, Bereiweriso LOF, 1996. Environmental health hazards and accidents: Experience from rural Rivers State Nigeria. Presented at the EBAN conference, November, Ekpoma, Nigeria.

Asher CJ, Edwards DG, Howeler R, 1980. Nutritional disorders of cassava. Dept. of Agric. Univ. of Queensland, St. Lucia, monograph.

Atlas RM, 1981. Microbial degradation of petroleum hydrocarbons: an environmental perspective. Microbiol Rev, 45(1): 180-209.

Atuanya El, 1987. Effect of oil pollution on physical and chemical properties of soil: a case study of waste oil contaminated Delta soil in Bendel State. J Appl Sci, 5: $23-8$.

Barke R, 1984. Queensland Department of Primary Industries, Brisbane, Australia, Personal Communication.

Bedient PB, 1994. Groundwater Contamination, Transport and Remediation, Prentice Hall PTR.

Benton JJ, 2003. Agronomic handbook; management of crops, soils and their fertility. CRC press LLC. USA.

Brooks RR, 1998. Plants that Hyper-accumulate Heavy Metals. Wallingford: CAB International. Oxon, UK. 384.

Buol SW, Couto W, 1981. Soil fertility capability assessment for use in the humid tropics. In: D.J. Greenland (ed.). Characterization of soils in Relation to their classification and management for Crop Production: Examples form some Areas of the Humid Tropics. Claredon Press, Oxford, 254- 261 pp.

Carrasqueros DA, Flores I, Perozo C, Pernalete S, 2006. Immobilization of lead by vermicompost and its effect on white bean (Vigna sinensis var. Apure) uptake. International J Environ Sci Technol, 3(3): 203-2.

Chaîneau $\mathrm{CH}$, Morel JL, Oudot J, 1998. Phytotoxicity and plant uptake of fuel oil hydrocarbons. J Environ Qual, 26: 1478-1483.

Charreau C, 1974. Soils of tropical dry and dry-wet climatic areas of West Africa and their use and management, Agron, Mimeo 74-26, Dept. of Agron., Cornell Univ., Ithaca, N.Y.

Chu W, Chan $\mathrm{KH}$, 2003. The mechanism of the surfactant aided soil washing system for hydrophobic and partial hydrophobic organics. Sci Total Environment, 307: 83 - 92.

Curtis EJ, Durran CK, Harman MM, 1975. Nitrification in rivers in the Trent basin. Water Res, 9: 255-268.

Dabibi LG, 1995. A paper presented by Shell Petroleum Development Company of Nigeria Limited on Sub-Theme: Entomology and Agricultural Extension Service. The SPDC (East) Experience: Operational Details. 28th November, Port Harcourt, Nigeria.

Ewuesie JV, 1998. Elements of tropical Ecology, Heinemann Educational Books, Inc., London. Envir-Health Consultants, 1995. Files on petroleum hazards (Pers. Comm.).

De Saussure NT, 1804. Recherches Chimiques sur la Vegetation Nyon Paris. In Soil Testing and Plant Analysis revised edition Walsh LM and Beaton J D (ed) (1963). Soil Sci Soc Amer Inc Madison Wisconsin, USA.

Edwards NT, 1983. Polycyclic aromatic hydrocarbons (PAHs) in the terrestrial environment - a review. J Environ Qual, 12: 427-441.

Ekpo MA, Nwankpa II, 2006. The effect of crude oil on microorganisms and growth of ginger (Zingiber officinale) in the tropics. J Sust Trop Agric Res, 16: 67-71

Ekpo MA, 2002. Microbial degradation of petroleum drilling and activities and plant root development. World J Biotech, $3: 377-86$.

Enwezor WO, Moore AW, 1966. Phosphorus status of some Nigerian soils. Soil Sci, 102:322-328.

Eilitta M, Mutsaers HJW, Walker P, 1991. An in-dept. agronomic survey of maize yield differences in South-Western Nigeria. Paper presented at the Farming Systems Symposium, Michigan State University, October, 1991, USA.

FACU, 1993. Federal Agricultural Coordination (FACU), Environmental Impact Assessment of the National Fadama Development Project (Southern States, Nigeria), 1-145pp.

FAO/UNESCO, 1974. Soil map of the world, FAO/UNESCO project. Key to soil units for the world map of the world, FAO, Rome 16p.

Fetter CW, Sloey WE, Spangler FL, 1978. Use of a natural marsh for waste water polishing. J Water Pollut Control Fed, 50: 290-307.

Flathman PE, Jerger D, Exner JE, 1993. Bioremediation: Field
Experience, Lewis, Boca Raton, FL.

Fries GT, 1982. Potential polychlorinated biphenyl residues in animal products from application of contaminated sewage sludge to land. $\mathrm{J}$ Environ Qual, 11: 14-20.

Fyfe WS, Kronberg BI, Leonardo OH, Olorunfemi N, 1983. Global Tectonics and agriculture: a geochemical perspective. Agric Ecosyst Environ, 9: 383-399.

Gaskin JW, Speir RA, Harris KR, Lee RD, Morris LM, Das KC, 2007. Effect of two types of pyrolysis chars on corn yield, soil nutrient status, and soil $C$ in loamy sand soil of the south eastern United States. Madison, Wisc.: ASA-CSSA-SSSA International Meetings.

Geering HR, Hodson JF, 1969. Micronutrient cation complexes in soil solution. Soil Science Society of America Proc, 33: 54-59.

Gill IS, Nyawuame HGK, Eihkhamelor AO, 2003. Effect of crude oil on the growth and anatomical features of chromolena odorota I. K \& R.

Greenland DJ, 1958. Nitrate fluctuations in tropical soil. J Agric Sci Camb, 50: 32-91.

Griffith G, 1951. Factors influencing nitrate accumulation in Uganda soils. Emp J Expl Agric, 19: 1-12.

Gueu, S, Yao B, Adouby K, Ado G, 2007. Kinetics and thermodynamics study of lead adsorption on the activated carbons from coconut and seed hull of the palm tree. Int J Environ Sci Technol, 4(1): 11-7.

Hahn SK, 1977. Sweet potato ecophysiology of tropical crops, Academic Press Inc; New York. pp. 248 - 327.

Handy F, 1946. Seasonal fluctuations of soil moisture and nitrate in a humid tropical climate. Trop Agric (Trin), 23:40-49.

Hanway JJ, 1962. Corn growth and composition in relation to soil fertility: 111. Percentages of $\mathrm{N}, \mathrm{P}$ and $\mathrm{K}$ in different plant parts in relation to stage of growth. Agron J, 54: 222-229.

Hendershot $\mathrm{WH}$, Lalande $\mathrm{H}$, Duquette $\mathrm{M}, 1993$. Soil reactions and exchangeable acidity, pp. 141-142, In: M. R. Carter, (ed.)- Soil Sampling and Methods of Analysis. Canadian Society of Soil Science, Lewis Publishers, Boca Raton, Florida.

Herbert E, Benscha PM, Novak JM, 1993. Pyrene sorption to watersoluble organic carbon Environ. Sci.Tech .27:398403.

Howeler RH, 1978. The mineral nutrition and fertilization of cassava. In: Cassava Production Course. Centro Internacional de Agricultura Tropical (CIAT), Cali, Colombia, pp. 247-292.

Howeler $\mathrm{RH}$, Bouldin DR, 1971. The diffusion and consumption of oxygen in submerged soils. Soil Sci Soc Am Proc, 35: 202-208.

Hinchee RE, Means JL, Burrisl DR, 1995. Bioremediation of Inorganics. Battelle Press, Columdus, $\mathrm{OH}$.

Ibedu MO, 1982. Phosphorus status of some saline and non-saline hydromophic soils from the Niger Delta of Nigeria. MSc. Thesis, Department of Agronomy, University of Ibadan, Nigeria.

lloeje NP, 1976. A new Geography of Nigeria, Longman Nigeria Limited, Ibadan, 26-33 pp.

IITA, 1979. Selected methods for Soil and Plant Analysis. IITA Manual Series. No.1.IITA. Ibadan. Nigeria, p. 70.

Isichei AO, Moughalu II, 1992. The effects of tree canopy cover on soil fertility in a Nigerian Savanna. J Trop Ecol, 8: 329-338.

Jones JB, 1967. Interpretation of plant analysis for several agronomic crops. pp. 49-58 In: R. C. Dinauer (Ed.), Soil Testing and Plant Analysis. Part II, Plant analysis. Soil Sci Soc Arner, Madison, Wisc.

Jones JB, 1973. Plant analysis as an aid in fertilizing corn and grain sorghum. p. 349-364. In L.M. alsh and J.B. Beaton (ed.) Soil testing and plant analysis. SSSA, Madison, WI.

Jones MJ, Wild A, 1975. Soils of the West African Savannah. Commonwealth Bureau of Soils, Technical Communication No. 55 Harpenden, England.

Kampfer P, Steiof M, Dott W, 1991. Microbial characterization of a fueloil contaminated site including numerical identification of heterotrophic water and soil bacteria. Microb Ecol, 21:227-251.

Kang BT, Wilson. GF, 1987. The development of alley cropping as a promising agroforestry technology. In: Steppler, H.A. and P.K.R. Nair (eds.) Agroforestry : A Decade of Development Nairobi, Kenya: ICRAF.

Khattak RA, Page AL, 1992. Mechanisms of manganese adsorption on soil conslltuenb. In: Adriano D.C (ed). Biogeochemistry Trace Metals. Lewis Publ Boca Raton, Florida, USA. 383-400.

King RB, Long GM, Sheldon JK, 1997. Practical Environmental Bioremediation: The Field Guide, 2nd ed., Lewis, Boca Raton, FL. 
National Research.

Lal $R, 1979$. Physical characteristics of soils of the tropics: determination and management. In: Lal, R., Greenland, D.J. Eds., Soil Physical Properties and Crop Production in the Tropics. Ž. Wiley, Chichester, pp. 7-44.

Lakanen E, Erviò R, 1971. A comparison of eight extractants for the determination of plant available micronutrients in soils. Acta Agr Ferm.

Lee DY, Chen ZS, 1994. Plants for cadmium polluted soils in Northern Taiwan. In: Adriano D.C, Chen ZS, Yang S.S (eds). Biogeochemistry of Trace Elements. A Special Issue of Environmental Geochem and Health, 16: 16170.

Le Mare PH, 1981. Phosphorus sorption and release. In: Greenland, D.J. (Ed.), Characterization of Soils. Clarendon Press, Oxford, pp. 97-134.

Lockman RB, 1969. Relationship between corn yields and nutrient concentration in seedling whole plant samples. Agronomy abstracts. Madison, WI: American Society of Agronomy.

Lyons WC, 1996. Standard handbook of Petroleum and Natural Gas Engineering Gulf Publishing Company, Houston.

Macy $P, 1936$. The quantitative mineral nutrient requirement of plants. Plant Physiol, 11:749-764.

Marschner H, 1995. Mineral nutrition of higher plants (2nd ed.). London: Academic Press.

Manahan SE, 1994. Environmental Chemistry. CRC Press. Inc. Florida, 811.

Mansfield JE, 1979. Land capability for annual rainfall arable crops in Northern Nigeria based on Soil physical limitations. In: R. Lal and D.J. Greenland (Eds.), Soil Physical Properties and Crop Production in the tropics. John Wiley and Sons, New York, 407-426pp.

Melsted SW, Motto HL, Peck TR, 1969. Critical plant nutrient composition values useful in interpreting plant analysis data. Agron. J, 61:17-20.

Mench, M, Didier VL, Loffler M, Gomez A, Masson P, 1994. Mimicked in situ remediation study of metal-contaminated soils with emphasis on cadmium and lead. J Environ Qual, 23: 58-63.

Moorman FR, Vorley JAA, Baker RM, Baker KF, Hughes JC, Brown G, 1981. Profile locations, descriptions and analysis. In: D. J. Greenland (ed.) Characterization of soils, 284-421 pp J. Wiley and Sons, London.

Moorthy SN, 2002. Physicochemical and functional properties of tropical tuber starches: A Review. Starch/Starke, 54, 559-592.

Murat RC, 1972. Stratigraphy and paleogeography of creataceous and lower Tertiary of Southern Nigeria. In: Dessauvagie, T.F.J and Whiteman, A.J (eds) 251-266pp.

Mutsaers HJW, Weber GK, Walker P, Fisher NM, 1997. A Field Guide for On-Farm Experimentation. The International Institute of Tropical Agriculture (IITA)/CTA/ISNAR. 48-55pp.

National Research Council (NRC), 1993. In situ Bioremediation: When does it work. National Academy Press, Washington, DC.

Norris, RD, Hinchee RE, Brown R, McCarty PL, Semprini L, Wilson JT, Kampbell DH, Reinhard M, Bouwer JE, Borden PC, Vogel MT, Thomas JM, Ward CH, 1993. Handbook of Bioremediation. Lewis, Boca Raton, FL.

Odjegba VJ, Sadiq, AO, 2002. Effects of spent engine oil on the growth parameters, chlorophyll and protein levels of Amaranthus hybridus L. The Environmentalist, 22: 23-28.

Odu CTI, Eurusoso OF, Nwobosh IC, 1988. Environmental Study of the Nigerian Agip Oil Company Operational Areas, Soil, Fresh Water vegetation -lbadan: University of Ibadan Press.

O'Connor GA, 1998. Fate and potential of xenobiotics. In: Beneficial Co-utilization of Agricultural, Municipal, and Industrial By-products. Brown, S., Angle, J.S., and Jacobs, L., Eds. Kluwer Academic Publishers, Dordrecht, the Netherlands. pp. 203-217.

Ojanuga AG, Lekwa G, Okusami TA, 1996. Distribution, classification and potentials of wetland soils of Nigeria monograph No 2. Soil Science Society of Nigeria, 1-24.

Onweremadu EU, Ndukwe OC, Okoroafor GF, 2008. Characterization and removability of priority pollutants in an oil-spilled site using composted Cassava sludge. Life Sci J, Vol 5, No 3.

Osiname OA, Simba L, Bartlet CD, Mayala R, Kasongo K, 1991. Onfarm evaluation of improved cassava varieties in the Kasangulu Zone of Bas-Zaire. In: H.J.W. Mutsaers and P. Walker (Eds). On-Farm Research in Theory and Practice. IITA, Ibadan, Nigeria. 204 pp.

Patrick WG Jr, Delume RD, 1976. Nitrogen and phosphorus utilization by Spartina alterniforna in salt mark in Barataria Bay, Louisiana. Estuarine Coastal Mar Sci, 4: 59-64.

Patrick WH Jr, Reddy KR, 1976. Nitrification identification reactions in flooded sols and sediments dependence on oxygen supply and ammonium diffusion. J Environ Qual, 5: 469-472.

Paul EA, Clark F E, 1989. Soil microbiology and biochemistry Academic press. San Diego. CA.

Peverill KI, 1993. Soil testing and plant analysis in Australia. Australian J Exp Agric, 33: 963-971.

Peverill KI, Sparrow LA, Reuter DJ (eds.) 1999. Soil Analysis. An Interpretation Manual. CSIRO Publishing, Collingwood.

Purseglove JW, 1992. Tropical Crops. Diocotyledon. Longman Nigeria. p.710.

Ram NM, Bass DH, Falotico R, Leahy M, 1993. A decision framework for selecting remediation technologies at hydrocarboncontaminated sites. J Soil Contaminat, 2(2): 167-189.

Reddy KR, Patrick WH Jr, Phillips RE, 1980c. Evaluation of selected processes controlling nitrogen loss in flooded soils. Soil Sci Soc Am J, 44: 1241-1246.

Reddy KR, Patrick WH Jr, 1984. Nitrogen transformations and loss in flooded soils and sediments critical reviews in Environmental control. 13(4): 273-309.

Reuter DJ, 1986. In: Reuter DJ, Robinson JB, editors. Plant analysis: an interpretation manual. Melbourne: Inkata Press, 38-99.

Reuter DJ, Robinson JB, 1986. Plant analysis: An Interpretation Manual 36p.

Rosenberg E, 1992. The hydrocarbon-oxidizing bacteria. In: Balows, A., Truè per, H.P., Dworkin, M., Harder, W., Schleifer, K.-H. (Eds.) The Prokaryotes. Springer-Verlag, New York, pp. 446-459.

Sahastrabudhe S, Modi VV, 1986. Use of Microbes in Environmental Improvement (Bisen, P.S. CBS Publishers and Distributors, Bhola Nath Nagar, India. 1:1 - 7pp.

Sanchez PA, Salinas JG, 1982. Low-input technology for managing Oxisols and Ultisols in tropical America. Adv Agron, 34: 280-292.

SAS, 1985. SAS User Guide, Statistical Analysis Systems Institute Inc. cary: pp. 25-36.

Sekar, M, Sakthi V, Rengaraj S, 2004. Kinetics and equilibrium adsorption study of lead (II) onto activated carbon prepared from coconut shell. J Colliery Int Sci, 279(2): 307-13

Sikkema J, deBont JAM, Poolman B, 1995. Mechanisms of membrane toxicity of hydrocarbons. Microb Rev, 59: 201-222.

Sindi K, 2015. Scaling up Sweet Potato through agriculture and nutrition (SUSTAIN) in Rwanda. In: International Potato Centre (CIP), editor. Nairobi, Kenya: International Potato Centre (CIP).

SPDC, 1995. Shell Petroleum Development Company of Nigeria Limited (SPDC), 1991. Review of Community and Environment April, 1995. Public affairs (RICL), Freeman House, 21/22 Marina, Lagos, Nigeria.

Stewart M, Jardine P, Barnett M, Mehlhorn T, Hyder L, McKay L, 2003. Influence of soil geochemical and physical properties on the sorption and bioaccessibiltiy of Chromium (III). J Environ Quality; 32: 129 -37.

Troug E, Berger KC, Attoe OJ, 1953. Response of nine economic plants to fertilization with sodium. Soil Sci. Soc. Am. J. 76: 41-50.

Turner FT, Patrick WH Jr, 1968. Chemical changes in water logged soils as a result of oxygen depletion. Trans. $9^{\text {th }}$ Int. Congr. Soil Sci. (Australia), 4, 53 p. Techicon Industrial Corp., Industrial Method No.447-77A. Tarry Town, New York.

Tyner EH, 1947. The relationship of corn yield to leaf nitrogen phosphorus and potassium content. Soil Sci Soc Am Proc, 11: $317-$ 323.

Udo FO, 1973. Availability of native and applied phosphorous to maize (Zea mays L.) in some Nigerian soils. Ph.D Thesis, University of Ibadan, Ibadan, Nigeria.

Ulrich A, 1949. Critical nitrate levels of sugar beets estimated from analysis of petiole and blades with special reference to yields and sucrose concentrations. Soil Sci, 69: 291-309.

Ulrich A, Hills FJ, 1967. Principles and Practices of plant Analysis 1124. In soil Testing and Plant Analysis Part 11, SSS .A Special Pub series No 2, Soil Sci Soc Amer Madison Wis, USA. 
Urum, K, Pekdemir R, Ross D, Grigson S, 2005. Crude oil contaminated soil washing in air sparging assisted tank reactor using biosurfactants. Chemosphere, 60: 334-343.

Uzu FO, Juo ASR, Fayemi AAA, 1975. Forms of phosphorus in some important agricultural soils of Nigeria. Soil Sci, 120: 212-218.

Weir RG, 1983. Tissue analysis for pasture and field crops. ,'JC' South Wales Department of Agriculture Advisory Note No. 11/83.

Wilson MA, 1987. NMR Techniques and Applications In: Geochemistry and Soil Chemistry. Pergamon Press, Oxford.

Wooley JT, 1957. Sodium and silicon as nutrients for the tomato plant. Plant Physiol. 1:317-321.

Woolfe J, 1992. Sweet potato: An untapped food resource. Cambridge University Press, Cambridge, UK.

World Bank, 1992. Forestry Sector Review Report No. 10744 - UNI.
Citation: Otaiku AA, 2019. Effects of oil spillage on soils nutrients of selected communities in Ogoniland, south-eastern Niger Delta, Rivers State, Nigeria. Int J Ecol Ecosolution, 6(3): 23-36. 